of the breeding season from the other (right) hand. The comparison both of Kammerer's pictures in his original paper (A.f. Entwickl. mech., 45, 323, 1919, Pls. x., xi.) or in his "Inheritance of Acquired Characteristics," Boni and Liveright, New York, I924 (Figs. IO-II, facing p. 62) and of the section photographed in America with nuptial pads of other Anura, show clearly that the callosities differ from all other known pads, resembling most those of other Discoglossidæ, as Bombinator, but still Discoglossus pictus (after Lataste; see Kammerer, I924, Fig. I I N. 3). This had already been pointed out by $\mathrm{Mr}$. Perkins (NATURE, August 18, 1923, p. 238). Lastly, it may be mentioned that quite recently the possibility of Alytes developing nuptial pads has been shown in a specimen found in Nature and examined by $R$. Kändler (Jenaische $Z$., 60, 175, I924, P1. Io, Fig. I2). Although it is only just a beginning of callosities in one male taken in Westfalen (Germany), when compared with the usual smooth surface of the Alytes hand it becomes significant. Kändler found the callosities in this one male on the palmar and dorsal side of the thumb, on the inner side of the third and fourth finger. The callosities resemble those which Kammerer figured for the $F_{2}$ generation of waterbred Alytes (l.c. Pl. xi. Fig. 4). There were no typical nuptial pad-glands. Kändler also questions if those described by Kammerer were of this character, as Kändler's females showed the same type of gland with granular content too. But no females showed callosities. Kändler has also figured the nuptial pad of other Anura, i.e. Bombinator igneus (Pl. 1o, Figs. 8A, 9). This figure is in accordance with that of Lataste.

Whilst it is possible to come to a probable solution with respect to the spiculæ, we have not been able to elucidate the origin of the black substance. It is clear that it has nothing to do with the black pigment often seen in nuptial pads of Anura other than Alytes, or with the patches described and in the progeny of non-egg-carrying Alytes males by Kammerer, I909.
The only possibility we can think of is that some one has tried to preserve the aspect of such black nuptial pads in fear of their vanishing by the destruction of the melanin through exposure to the sun in the museum case, by injecting the specimen with India ink. Kammerer himself was greatly astonished at the result of the chemical tests, and it ought to be stated that he had been asked and had given his consent to the chemical investigations. $\mathrm{He}$ would suggest that somebody had made such injections to get him into difficulties were it not that he remembers the black substance to have been in the same place and amount even in the living animal (letter to Przibram, February 18, 1926). So the case remains obscure.

We may conclude as a result of these observations :

(I) The only one of Kammerer's specimens of Alytes still preserved is not valid as a proof of the nuptial pads, at least not in its present state of preservation.

(2) No asperities are to be seen now, but by photographs taken before the specimen was sent to England it must be inferred that the spiculæ have been lost through the shaking of the voyage and repeated handling.

(3) Photomicrographs of the sections said to have been prepared from the skin of the same specimen some time before its preservation in the height of the breeding season show in several points different characters from nuptial pads of other Anura, even of Bombinator, coinciding more closely with those of Discoglossus (next relative to Alytes), and the picture of a rudimentary nuptial pad found on a male Alytes in Nature by Kändler (1924).

(4) The black substance in the whole specimen has nothing to do with melanin and is not restricted to a nuptial pad region.

(5) With this conflicting evidence it is greatly to be desired that the experiments of Kammerer on Alytes may be taken up again by some one of equal skill in rearing Anura.

\title{
The Progress of Geological Survey in Great Britain.
}

THE area described in the first ${ }^{1}$ of the Memoirs of the Geological Survey of Great Britain referred to below lies in Ross-shire and Sutherland. The north-western corner is occupied by Lewisian, Torridonian and Cambrian rocks, all of which have been involved in the great Caledonian thrusts of the N.W. Highlands. Of special interest are the alkaline igneous rocks of Loch Ailsh. They form a composite laccolith of post-Cambrian and pre-thrusting age, made up of types ranging from perthosite (a new type composed principally of perthite) to pyroxenite, and resembling in many ways the well-known Oslo suite of rocks made classic by Brögger. Convincing evidence is adduced to show that the alkaline character is original, and quite independent of the intimate association of the intrusion with the Cambrian dolomites. Another feature of petrological importance is the description of the newer igneous rocks, which here present clear evidence of permeation and hybridisation.

The area dealt with in the second memoir ${ }^{2}$ in our list, Golspie, lies to the east of the preceding, and includes the coast of Sutherland from Dornoch to Helmsdale. The earlier chapters are devoted to the physical features, and to the schists and gneisses

${ }_{1}$ The Geology of Strath Oykell and Lower Loch Shin. (Explanation of Sheet 102 of the Geological Map of Scotland.) By Dr. H. H. Read, J. Phemister and G. Ross, with contributions by C. H. Dinham and M. Macgregor. Pp. vi $+220+2$ plates. 6s. net.

The Geology of the Country around Golspie, Sutherlandshire. (Explanation of Sheet 103 of the Geological Map of Scotland), including a description of the Mesozoic Rocks of East Sutherland and Ross. By Dr. G. W. Lee, Dr. H. H. Read, G. Ross and J. Phemister. Pp. vi+r $43+$ r plate. $3 s .6 d$. net.

$$
\text { NO. 2962, VOL. I I } 8]
$$

belonging to the Moine series and the older and newer igneous rocks associated with them. The marginal complex of injected and other metamorphic rocks around the Rogart granite is fully described, and hybrids like those alluded to above also occur. The old Red Sandstone covers considerable areas in the sheet, and along a narrow coastal strip Mesozoic rocks are present, ranging from the trias to the Kimeridgian. The final chapter gives an account of glacial phenomena, peat deposits, and raised beaches.

Iona and Staffa are visited every summer by an increasingly large number of tourists, and those who are interested in geology will appreciate the publication of a Memoir referring to this region. ${ }^{3}$ Those who are not will become interested despite themselves, for the islands abound in geological features which are part of their attraction. The famous Ardtun Leaf Beds and Macculloch's Tree are fully described; and the columnar basalts of Fingal's Cave and other parts of Staffa are discussed on the lines followed in the recent Memoirs on the Isle of Mull.

The account of the geology of the extreme north of England given in the Memoir on Berwick and the neighbouring country ${ }^{4}$ is welcome as a sign that the

3 The Geology of Staffa, Iona, and Western Mull. (A Description of Sheet 43 of the Geological Map.) By E. B. Bailey and E. M. An lerson, with contributions by G. A. Burnett, J. E. Richey, Dr. G. W. Lee, W. B. Wright and G. V. Wilson, and Petrological Notes by Dr. H. H. Thomas. Pp. iv + ro $+\mathrm{I}$ plate. 3 s. net.

The Geology of Berwick-on-Tweed, Norham and Ssremerston. (Explanation of New Series One-inch Sheets I and 2.) By A. Fowler. Pp. $x+58+2$ plates. Is. $6 d$. net. 
re-survey of Northumberland is now well under way. The chief points of interest are the descriptions of the Scremerston coalfield and the very striking coast sections to the north of the Tweed. Memoirs on the sheets to the south are due for early publication, and should be of importance in so far that they will contain references to the northern boundary of the Whin Sill It is in itself significant that this Memoir, the first of the promised series, contains no mention of any igneous rocks.

The greater part of the Pottery coalfield of North Staffordshire is included in the sheet described in the Memoir on Stoke-upon-Trent. ${ }^{5}$ An account of the coal measures with their important coal seams and iron ores naturally takes first place. There is also a valuable chapter on faults and folds; and as a feature appearing for the first time in this edition, descriptions of the post-Triasic Bullerton dyke and of the other intrusions of the area are given. It is interest-

5 The Geology of the Country around Stoke-upon-Trent. (Explanation of Sheet 123.) By Dr. Walcot Gibson, with contributions by C. B. Wedd and Dr. A. Scott. Third edition. Pp. viitir2. 2s, $6 d$. net. ing to notice that Dr. Scott, who has studied the Tertiary and Carboniferous alkaline rocks of Scotland, directs attention to the petrological affinities of the former with the intrusive rocks of North Staffordshire. He thinks that the Rowley Regis and Clee Hill rocks are likely to be also of Tertiary age.

Passing now to Epping Forest and the eastern suburbs of London, ${ }^{6}$ we find only Eocene, Pleistocene and later deposits. The Chalk, however, underlies the whole area, and the question of deep-seated water supplies is discussed, and illustrated by a contour map of the sub-Tertiary Chalk surface. On the south the subsoil consists mainly of the deposits made "by the Thames; the central part is chiefly London clay; while to the north the region is diversified with hills capped with Bagshot sand and glacial deposits. These beds are discussed with special reference to sanitation and agriculture.

6 The Geology of the Country around Romford. (Explanation of Sheet 257.) By H. G. Dines and F. H. Edmunds. Pp. xiii $+53+2$ plates. s. 6 d. net.

London and Edinburgh : H.M. Stationery Office; Southampton : Ordinance Survey Office, 1925 and 1926.

\section{Air Pollution and its Prevention.}

THE citizens of Leeds, under the auspices of the Mayor and City Council, have instituted a campaign against smoke to commemorate in a practical form the tercentenary of the granting of the statute to the city. In connexion with this effort, a pamphlet entitled "Clean Air for Leeds" has been prepared by a Committee, of which Prof. J. B. Cohen is chairman, formed on the invitation of the Lord Mayor to consider the question of " a cleaner city on the lines of smoke abatement." The pamphlet has been prepared for free distribution, and aims at informing the public as to the present condition of the smoke problem.

Leeds is to be congratulated on facing her own smoke problem in this way. A visitor, unless from another Midland city, cannot help being struck by the prevailing sooty blackness of the buildings. It is surely a merciful provision of Nature that people adjust themselves so easily to environment; had this not been so, life in some of our smoke-blackened cities must appear scarcely worth living. It is, however, this adjustment to environment which blinds our eyes more or less to the true condition of affairs. Leeds has a useful field for effort here. The pamphlet gives a short analysis of the problem of smoke abatement and the remedies available. The sources of air pollution, cause, nature, and effects of smoke are all dealt with briefly.

The general conclusions of the Departmental Committee on Smoke Abatement are quoted, and it is clear enough that this committee had no hope of a solution of the problem by the initiative of local authorities unless subject to the stimulus of Government. The new Bill now before Parliament must provide the necessary stimulus or it will not go very far towards a solution.

The Leeds pamphlet should be of great use in keeping the problem before the public mind. Reference is made on page 24 to the standard gauge used by the Advisory Committee on Atmospheric Pollution, and the Leeds committee criticises this gauge on the grounds that "the amount of solid matter is largely dependent on the situation with regard to the wind and the nature of the ground on which the gauge rests." The Committee then proceeds to recommend a method devised by Prof. Cohen many years ago, involving the exposure, in different localities, of glass plates, upon which some of the deposited matter adheres. These plates are afterwards washed in running water under a tap, and the deposit estimated by its opacity, or other means. The Advisory Committee, we believe, had this method before it when considering the most suitable means for measuring deposited impurity, and the method was discarded as not fulfilling the necessary conditions. While the exposed plate method has all the drawbacks attributed by the Leeds committee to the standard deposit gauge, it has also others of its own, which influenced the Advisory Committee in deciding to adopt the gauge method. The plates cannot be any more independent of position or wind than the gauges, while the deposit retained by the plates is not the total but some unknown and variable fraction of it, depending on the stickiness of the deposit, whether the plates are wet or dry, the weather, and so on. It may also be supposed that a plate which has received a first deposit of tarry soot will be more effective as a trap than one which starts with a less sticky layer of ash or grit. The only sound procedure is to catch in some way the whole of the deposit--hence the Advisory Committee's standardised gauge.

It is to be hoped that Leeds will not depart from this method of measuring deposit, as a great part of the value of the results lies in their being comparable with those from other cities.

The open coal fire is discussed in the pamphlet, and the conclusion is given that raw coal cannot be burnt in an open grate without the production of smoke. The use of smokeless sources of heat is recommended, of which gas, coke, and electricity are specifically mentioned and discussed. The advantages of the gas fire, its cleanliness and cheapness, are referred to, while the use of coke in domestic fires is advocated; but, as the pamphlet goes on to say, " it is not every kind of fireplace nor every kind of coke which is suitable for burning in an open fire." The relative costs of heating by coke, coal, gas, and electricity are discussed; the figures arrived at indicate coke to be much the most economical source of heat.

A section at the end deals with the law relating to the smoke nuisance, and the new Government Bill is discussed. The committee, in its final recommendations, lays great stress upon the need to educate the public in the use of smokeless methods, and, on the whole, it is to be congratulated on its public-spirited efforts to clean the air of Leeds. 